\title{
World Journal of Indolent complication after
Pediatric Surgery percutaneous endoscopic gastrostomy: a case report of gastric fistula
}

\author{
Anand Gourishankar
}

To cite: Gourishankar A. Indolent complication after percutaneous endoscopic gastrostomy: a case report of gastric fistula. World JnI Ped Surgery 2020;3:e000202. doi:10.1136/wjps-2020-000202

Received 18 August 2020 Revised 7 October 2020 Accepted 9 October 2020

Check for updates

(C) Author(s) (or their employer(s)) 2020. Re-use permitted under CC BY-NC. No commercial re-use. See rights and permissions. Published by BMJ.

Department of Pediatrics, Pediatric Hospital Medicine, Children's National Medical Center, Washington, District of Columbia, USA

Correspondence to Dr Anand Gourishankar; agourishan@childrensnational. org
An adolescent patient developed vomiting 1 month after percutaneous endoscopic gastrostomy (PEG) insertion. A gastrostomytube contrast study confirmed the gastrocolic fistula. The gastrocolic fistula, a rare complication, should be considered in high-risk patients.

After the first PEG tube insertion by Dr Gauderer in $1979,{ }^{1}$ advances in the technique, use in adults and development of different types of tubes have helped various types of patients. Failure rates are similar between laparoscopic $(0.5 \%)$ and PEG $(0.9 \%)$ procedures; the later had a higher risk of complications of visceral injury and mechanical issues. ${ }^{2}$ Similar results were reported in a heterogeneous group of patients. ${ }^{3}$ However, PEG showed no differences in mortality or infection compared with percutaneous radiologic gastrostomy. ${ }^{4}$ Complications are inherent with any procedure; awareness of immediate and late complications of PEG insertion is vital. We discuss here a case pertinent to quiescent late ( $\geq 2$ weeks) complication.

An adolescent patient was neurologically devastated after a motor-vehicle-collision accident. The patient developed 3 days of vomiting 1 month after PEG insertion. The abdominal examination was soft and nondistended, with no organomegaly, and bowel sounds were present. The review of other systems was negative. There were no other accompanying signs or symptoms. The patient was not constipated, had no clinical concern for sepsis, and imaging was completed owing to the persistent vomiting.

A "scout film" of the abdomen showed a nonobstructive bowel pattern (figure 1A). The gastrostomy-tube contrast study revealed an immediate leaking of contrast from the stomach into the colon: a white arrow in figure $1 \mathrm{~B}$ indicated the stomach's contrast. The contrast entered immediately into the transverse colon (black arrow, figure 1C) and descending colon (black arrow, figure 1D).
An exploratory laparotomy found dense adhesions, colon being stuck to the abdominal wall, and a well-established gastrocolic fistula. After corrective surgery, the patient tolerated the enteral feeds.

Children undergo PEG, who have difficulty in swallowing and cannot maintain nutrition by mouth. A PEG placement is a safe alternative to an operative gastrostomy tube. Although PEG insertion is a safe procedure, gastrocolic fistula is a recognized complication. It is a challenge when children remain asymptomatic with gastrocolic fistula for a period.

PEG tube insertion is a blind transabdominal technique, and it can be inadvertently placed into the transverse colon. ${ }^{5}$ Apart from exit-site infection, ${ }^{6}$ peritubular leakages, migration of the device, ${ }^{78}$ or gastrocolic fistula are recognized complications. This fistulous complication may remain silent or present with non-specific symptoms. ${ }^{9}$ Thus, gastrocolic fistula must remain in the differential diagnosis. If in doubt, obtain a gastrostomy-tube contrast study as described in our case. The contrast will bypass a segment of the intestine to fill the distal portion via the fistula. The contrast may seep into the peritoneal cavity. Another option is to consider a CT abdomen. ${ }^{9}$

The case in the vignette had vomiting with no other concern. Previous case reports have described PEG insertion and poor weight gain with vomiting in 18 months $^{9}$ or fecal emesis in 2 weeks to 3 months. ${ }^{10}$ Patwardhan et al reported that complications could present from 1 day to 25 months of post-PEG insertion. ${ }^{5}$ The specific symptoms are abdominal pain in older children and undigested feed or formula per rectum. The risk factors attributed to a gastrocolic fistula are adhesions from previous abdominal surgery, colonic puncture during PEG placement, comorbidities, ${ }^{11}$ thoracoabdominal deformities, ${ }^{12}$ and tube migration with possible 

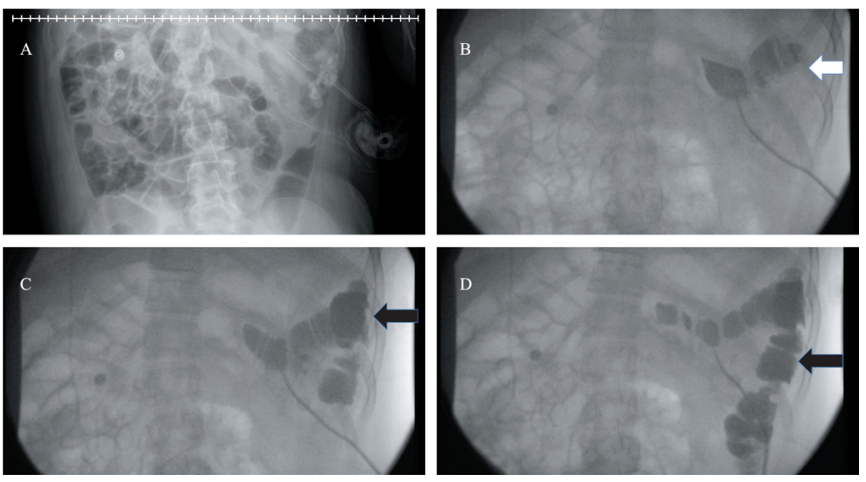

Figure 1 Contrast study of the gastrostomy tube showing contrast from the stomach directly into the colon.

overdistension of the stomach. We highlight the rare complication of PEG tube placement. It is important to have a low threshold for a diagnostic test and to correct any identifiable risk factor.

Evaluation for surgical complications in children with gastrostomy tubes must be considered in the differential diagnosis, and appropriate imaging study will help us to identify the problem. Early recognition and identification of risk factors for developing gastrocolic fistula will prevent delayed diagnosis.

\section{Twitter Anand Gourishankar @a_gourishankar}

Contributors GA contributed to investigation, visualization, original draft writing, review and editing.

Funding The authors have not declared a specific grant for this research from any funding agency in the public, commercial or not-for-profit sectors.

Competing interests None declared.

Patient consent for publication Not required.

Ethics approval This study was exempt from the ethical review committee of the hospital.

Provenance and peer review Not commissioned; externally peer reviewed.

Data availability statement № data are available.
Open access This is an open access article distributed in accordance with the Creative Commons Attribution Non Commercial (CC BY-NC 4.0) license, which permits others to distribute, remix, adapt, build upon this work non-commercially, and license their derivative works on different terms, provided the original work is properly cited, appropriate credit is given, any changes made indicated, and the use is non-commercial. See: http://creativecommons.org/licenses/by-nc/4.0/.

ORCID iD

Anand Gourishankar http://orcid.org/0000-0003-4344-7032

\section{REFERENCES}

1 Gauderer M. Twenty years of percutaneous endoscopic gastrostomy: origin and evolution of a concept and its expanded applications. Gastrointest Endosc 1999;50:879-83.

2 Baker L, Beres AL, Baird R. A systematic review and meta-analysis of gastrostomy insertion techniques in children. J Pediatr Surg 2015;50:718-25.

3 Suksamanapun N, Mauritz FA, Franken J, et al. Laparoscopic versus percutaneous endoscopic gastrostomy placement in children: results of a systematic review and meta-analysis. J Minim Access Surg 2017;13:81-8.

4 Strijbos D, Keszthelyi D, Bogie RMM, et al. A systematic review and meta-analysis on outcomes and complications of percutaneous endoscopic versus radiologic gastrostomy for enteral feeding. J Clin Gastroenterol 2018;52:753-64.

5 Patwardhan N, McHugh K, Drake D, et al. Gastroenteric fistula complicating percutaneous endoscopic gastrostomy. J Pediatr Surg 2004;39:561-4.

6 Ponsky JL, Gauderer MW, Stellato TA. Percutaneous endoscopic gastrostomy. review of 150 cases. Arch Surg 1983;118:913-4.

7 Huang SY, Levine MS, Raper SE. Gastrocolic fistula with migration of feeding tube into transverse colon as a complication of percutaneous endoscopic gastrostomy. AJR Am J Roentgenol 2005;184:S65-6.

8 Milanchi S, Wilson MT. Malposition of percutaneous endoscopicguided gastrostomy: guideline and management. J Minim Access Surg 2008;4:1-4.

9 Brown S, McHugh K, Ledermann S, et al. Ct findings in gastrocolic fistula following percutaneous endoscopic gastrostomy. Pediatr Radiol 2007;37:229-31.

10 Stefan MM, Holcomb GW, Ross AJ. Cologastric fistula as a complication of percutaneous endoscopic gastrostomy. JPEN J Parenter Enteral Nutr 1989;13:554-6.

11 Balogh B, Kovács T, Saxena AK. Complications in children with percutaneous endoscopic gastrostomy (PEG) placement. World J Pediatr 2019;15:12-16.

12 Fascetti-Leon F, Gamba P, Dall'Oglio L, et al. Complications of percutaneous endoscopic gastrostomy in children: results of an Italian multicenter observational study. Dig Liver Dis 2012;44:655-9. 